\title{
Changing patterns of population structure and gene flow at different spatial scales in Birgus latro (the coconut crab)
}

\author{
SHANE LAVERY*, CRAIG MORITZ \& D. R. FIELDER \\ Zoology Department and Centre for Conservation Biology, University of Queensland, Brisbane 4072, Australia
}

\begin{abstract}
The population structure of the coconut crab (Birgus latro) was studied by examining genetic variation at seven polymorphic enzyme loci. Individuals were collected from 10 locations (grouped in seven major populations) throughout the Indo-Pacific distribution of the species. Significant population differentiation was found among all seven major populations $\left(F_{\mathrm{ST}}=0.078, P<0.001\right)$ and among the six Pacific Ocean populations $\left(F_{\mathrm{ST}}=0.026, P<0.01\right)$. There were no significant differences in allele frequencies among adjacent Vanuatu islands separated by up to $200 \mathrm{~km}$. At any one location there were no significant changes in allele frequencies over time (up to 3 years). Estimates of gene flow varied considerably, depending on the method of calculation, but all supported the same interpretations of population subdivision. The pattern of population structure varied with the spatial scale under consideration. The Indian Ocean population (from Christmas Island) was clearly divergent from all Pacific populations, in the fashion of an island model. However, within the Pacific, the relation between genetic and geographical distance showed that the pattern of genetic variation closely resembled an isolation by distance model. Populations from adjacent Vanuatu islands exhibited panmixia.
\end{abstract}

Keywords: allozymes, Birgus latro, gene flow, Indo-Pacific biogeography, larval dispersal, population genetics.

\section{Introduction}

Species with planktonic larvae have the potential for long-distance dispersal, resulting in a high degree of genetic mixing of subpopulations. It might therefore be expected that, for such species, little genetic differentiation could accumulate between subpopulations (e.g. Waples, 1987; Palumbi, 1992). However, for a significant number of marine invertebrates this is not the case (Burton, 1983; Hedgecock, 1986). Species such as the American oyster, Crassostrea virginica (Reeb \& Avise, 1990), and the spiny lobster, Panulirus argus (Menzies, 1991), have relatively long-lived planktonic larvae (duration: $C$. virginica, 2-3 weeks; $P$. argus, 6-10 months) with a great potential for long-distance dispersal, yet have been shown to have genetically discrete populations, even within a continuous distribution. Possible reasons for this include: (i) larval retention mechanisms, such as larval behaviour and ocean currents (McConaugha, 1992), (ii) unrecognized

*Correspondence: Queensland Agricultural Biotechnology Centre, Level 4, Gehrmann Laboratories, University of Queensland, Brisbane 4072 , Australia. physical or historical barriers, such as divergent currents or ice-age land barriers (Reeb \& Avise, 1990), and (iii) local selection pressures (e.g., Koehn et al., 1980).

In this study, we examined genetic subdivision in the marine realm by analysing allozyme variation in the coconut crab (Birgus latro), which has marine planktonic larval stages, but has completely terrestrial juvenile and adult stages.

The coconut crab is the largest terrestrial arthropod, growing to $200 \mathrm{~mm}$ in carapace length and $4 \mathrm{~kg}$ in weight. The species' only requirement for the sea is for releasing eggs, which hatch on contact with sea-water. The larvae are planktonic in the water column for a period of 3-4 weeks before they settle as benthic glaucothoe, finally migrating onto land (Reese \& Kinzie, 1968; Schiller et al., 1991). B. latro is believed to have evolved from an anomuran hermit crab ancestor (Brown \& Fielder, 1991), and juveniles still retain the hermit crab habit of acquiring a mollusc shell for protection until they grow too large for available shells at about $20 \mathrm{~mm}$ in carapace length. B. latro is confined to tropical islands in the Indian and Pacific Oceans, from the coast of Africa in the west to the 
Tuamotu Archipelago in the east (Fig. 1). The numbers of this species have declined dramatically throughout its range in the past few decades (Wells et al., 1983). $B$. latro can no longer be found on many islands from which it was once recorded and is now rare on many others, although high densities can still be found in very remote locations. Human interference appears to be the cause of these reductions.

The extent of larval dispersal in B. latro is unknown, and there are limited data on the length of the larval stage outside the laboratory. Also, there is little reported on morphological differentiation of $B$. latro populations, despite anecdotal evidence for substantial polymorphism in coloration (Brown \& Fielder, 1991). Thus there is no existing indication of the possible extent of population subdivision in the species, or the geographical scale over which populations are genetically discrete.

The pattern of population structure in this species may resemble that of an island model, isolation by distance model, or panmixia (Richardson et al., 1986). The existence of planktonic larval dispersal in B. latro suggests that gene flow among populations may be high, and that there would not be discrete boundaries between populations. It may therefore be expected that the pattern of population structure will be most similar to an isolation by distance model on the large scale, but on the small scale of adjacent islands, panmixia may be expected. Alternatively, if genetically distinct 'islands' exist, then this may provide evidence for the presence of previously unrecognized barriers to larval dispersal in the Indo-Pacific, not only in this species, but perhaps in others with a similar distribution and mode of dispersal.

To determine which pattern of population structure occurs in B. latro, and at what spatial scale genetic differentiation is evident, this study used a hierarchical sampling strategy in examining genetic variation. This involved sampling populations from adjacent islands within a group, island groups within the one ocean basin and the Indian and Pacific Oceans.

Allozyme electrophoresis is a very effective tool in analysing population subdivision, by determining the levels of genetic differentiation among samples from different locations in relation to within-sample variation. Using this technique, population subdivision has been found in a number of other decapod crustaceans, such as the American lobster, Homarus americanus (Tracey et al., 1975), some penaeid prawns (Mulley \& Latter, 1981a, b; Salini 1987), the pink shrimp, Pandalus borealis (Kartavtsev et al., 1991), the palaemonid prawn, Macrobrachium rosenbergii (Lindenfelser, 1984), and the pea crab, Pinnotheres atrinicola (Stevens, 1991).

This study examined the degree and pattern of population subdivision in $B$. latro using allozyme electrophoresis. A previous study (Lavery \& Fielder, 1993) reported low allozyme heterozygosity but identified seven loci that were polymorphic within the Vanuatu population. Here we quantify levels of allozyme variation among localities at three different spatial scales to make inferences about patterns of population structure and gene flow (Slatkin, 1985). This, in turn, allows inferences to be made about the degree of interdependence of $B$. latro island populations, and about the influence of larval migration in determining the population structure of the species.

\section{Materials and methods}

\section{Sampling}

There was a three-level sampling hierarchy: islands within a group, island groups in the Pacific Ocean, and

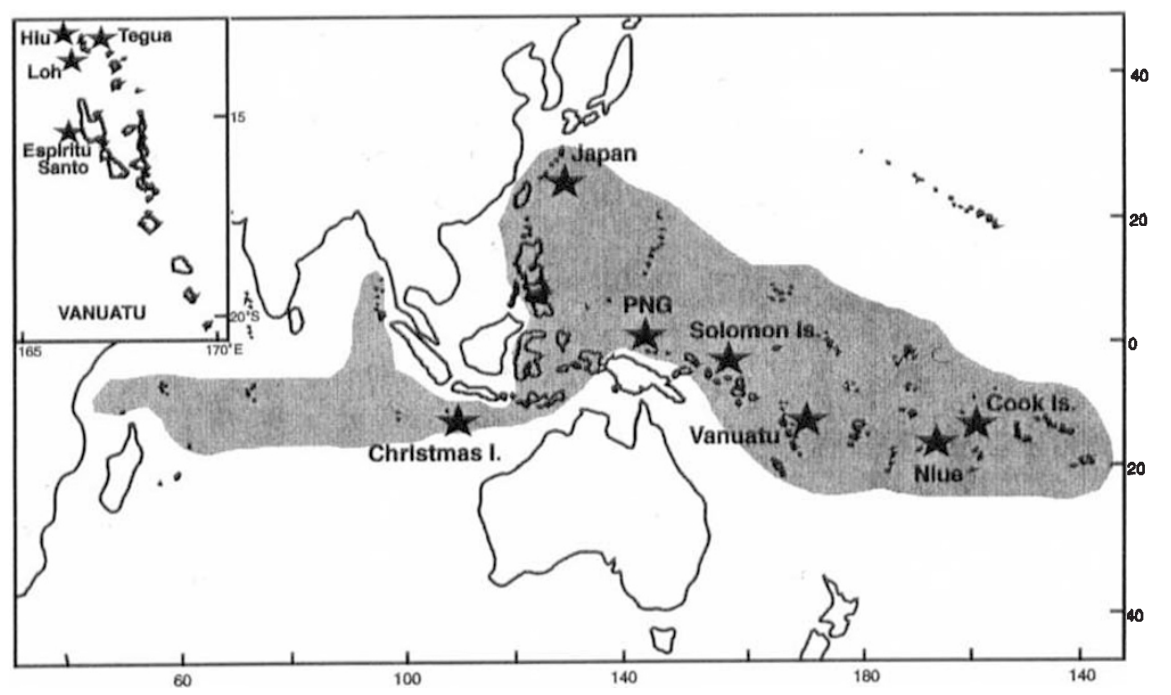

Fig. 1 Birgus latro Indo-Pacific distribution (shaded) and collection sites (stars). Inset: Vanuatu collection sites (stars).

(c) The Genetical Society of Great Britain, Heredity, 74, 531-541. 
Table 1 Birgus latro sample collections

\begin{tabular}{lccrr}
\hline & \multicolumn{3}{c}{ Sample sizes } & \\
\cline { 2 - 3 } Collection & 1989 & 1990 & 1991 & Total \\
\hline Indian Ocean & & & & \\
$\quad$ Christmas Island (Christmas Is.) & 27 & 24 & 30 & 81 \\
Pacific Ocean & & & & \\
$\quad$ Japan (Ishigaki-jima) & & & 21 & 21 \\
$\quad$ Papua New Guinea (Wuvulu I.) (PNG) & & & 18 & 18 \\
$\quad$ Solomon Islands (Malaita) & 45 & 29 & & 74 \\
$\quad$ Vanuatu (Total) & 21 & & & 188 \\
$\quad$ Hiu I. & & 39 & & 39 \\
$\quad$ Tegua I. & & 35 & & 35 \\
$\quad$ Loh I. & 58 & 35 & & 93 \\
$\quad$ Espiritu Santo I. & 18 & & 26 & 44 \\
$\quad$ Niue & & & 28 & 28 \\
$\quad$ Cook Islands (Suwarrow Atoll) & & &
\end{tabular}

the Indian and Pacific Oceans (Table 1; Fig. 1). Adult $B$. latro were obtained from four islands in Vanuatu. Individual islands from five other groups in the Pacific Ocean were sampled. One location, Christmas Island (an Australian Territory) was sampled in the Indian Ocean. Sample sizes per locality ranged from 18 to 81 (Table 1). Attempts to obtain individuals from other Indian Ocean locations proved unsuccessful. Replicate samples were obtained from Christmas Island, the Solomon Islands, Espiritu Santo and Niue to determine both the stability of allele frequencies over time, and sampling effects.

Individuals were transported either alive or frozen to the Brisbane laboratory. Tissue samples were prepared and water soluble enzyme extracts obtained using the methods outlined by Lavery \& Fielder (1993).

\section{Electrophoresis}

Horizontal starch gel electrophoresis (Shaklee \& Keenan, 1986) was used to detect genetic variation. From 59 putative enzyme loci surveyed, seven polymorphic loci have been identified previously from the Vanuatu population (Table 2; Lavery \& Fielder, 1993). The genotypes of all individuals were determined for each of these seven polymorphic loci. The remaining monomorphic loci were also screened for genetic variation in at least five individuals from each location. Allele and genotype frequencies were calculated for all collections. Genetic nomenclature follows that of Shaklee et al. (1990).
Table 2 Enzyme loci polymorphic in Birgus latro

\begin{tabular}{lcc}
\hline Locus & Abbreviation & Enzyme no. \\
\hline Glucose-6-phosphate isomerase & $G P I$ & 5.3 .1 .9 \\
Malate dehydrogenase-1 & $M D H-1$ & 1.1 .1 .37 \\
Malate dehydrogenase-2 & $M D H-2$ & 1.1 .1 .37 \\
Octanol dehydrogenase & $O D H$ & 1.1 .1 .73 \\
Peptidase(leu-gly-gly) & $P E P$ & $3.4 .--$ \\
Phosphoglucomutase-1 & $P G M-1$ & 5.4 .2 .2 \\
Phosphoglucomutase-2 & $P G M-2$ & 5.4 .2 .2 \\
\hline
\end{tabular}

\section{Statistical analysis}

The fit of genotype frequencies to Hardy-Weinberg equilibria was examined for each locus in each population using $\chi^{2}$ goodness-of-fit tests on all genotypes and also on the three genotypes obtained by pooling all alternate alleles (namely those other than the most common). These tests were carried out using the BIOSYS-1 computer program (Swofford \& Selander, 1981). Significance values of all $\chi^{2}$-tests were adjusted for multiple tests of the same hypothesis using the sequential Bonferroni technique (Lessios, 1992).

Heterogeneity of allele frequencies among samples was determined by contingency $\chi^{2}$-tests and $G$-tests (Sokal \& Rohlf, 1981). Genetic variance among locations was also examined using $F$-statistics (Nei, 1977; Wright, 1978). Values of $F_{\mathrm{ST}}$ (equivalent to Nei's $G_{\mathrm{ST}}$ ) were calculated using the methods of Wright (1978) and values of $\theta$ (conceptually very similar to $F_{\mathrm{ST}}$; Slatkin \& Barton, 1989; Chakraborty \& Danker- 
Hopfe, 1991) were calculated by the methods outlined in Weir \& Cockerham (1984). Values were tested for significance $\left(H_{0}: F_{\mathrm{ST}}\right.$ or $\left.\theta=0\right)$ using the $\chi^{2}$ method of Workman \& Niswander (1970) and the jackknifing and bootstrapping methods of Weir (1990) using his computer program DIPLOID (listed in Weir, 1990). Hierarchical $F$-statistics were calculated for three levels (among islands within a group, among island groups, and between Indian and Pacific Oceans) using the methods of Wright (1978) and Nei \& Chesser (1983).

Rogers's modified genetic distance (Wright, 1978) was calculated between all pairs of samples and used in a UPGMA cluster analysis of locations (Sneath \& Sokal, 1973). The pattern of genetic relationships among populations was investigated using the multidimensional scaling (MDS) approach suggested by Lessa (1990) and carried out using NTsYs-pc (Rohlf, 1990). Owing to the nonindependence of data points, the relationship between genetic and geographical distance was tested using a Mantel test (Smouse et al., 1986) performed by the NTSYs-pc computer package. Significance was determined using both an approximate $t$-test and a nonparametric test with 1000 random permutations of the matrices.

Estimates of gene flow were made using the relationship $F_{\mathrm{ST}}=(4 N m+1)^{-1}$ (Wright, 1978; where $\mathrm{Nm}$ is the effective number of migrants exchanged in each generation) to derive gene flow from $F_{\mathrm{ST}}$ and $\theta$.

\section{Results}

\section{Within population variation}

Allele heterozygosities were very similar among populations (Table 3). Although heterozygosities were slightly higher in the Niue and Japan populations, these two values were not significantly greater than those found in other populations (mean $H_{\text {exp }}=0.155$ ). None of the tests for fit of genotype frequencies to Hardy-Weinberg expectations gave significant results.

Replicate sampling in Christmas Island (three samples from consecutive years), Solomon Islands, Espiritu Santo and Niue (two samples each) revealed no overall significant differences in allele frequencies between sampling occasions. (This is an appropriate test for temporal differences in allele frequency as the number sampled was far less than one-tenth the proportion of the total population size; Waples 1989.) Although the numbers of individuals were small (Table 1), the lack of heterogeneity allowed us to assume that these replicate samples could be pooled for analysis among locations.

\section{Variation among island populations}

Allele frequencies in all the Vanuatu island collections were very similar, both among the northern Torres Group (Hiu, Tegua and Loh) and between the Torres Group and Espiritu Santo (Santo). No loci gave significant heterogeneity $\chi^{2}$-tests (Table 4 ), and the probability value of the test among all populations over all loci was 0.8 . All Vanuatu populations were thus pooled for further $\chi^{2}$ comparisons among populations.

Among all seven populations (Vanuatu populations pooled), there was a highly significant heterogeneity $\chi^{2}$ over all loci $(P<0.001$, Table 4). All loci except $G P I$ had allele frequency differences significant at the 0.05 level or lower. Considering just the six Pacific Ocean populations, there were again highly significant allele frequency differences $(P<0.001)$. Individual loci significant at the 0.05 level were $M D H-1, O D H, P E P$ and PGM-1 (Table 4).

To determine the precise geographical locations where genetic discontinuities occurred, pairwise $\chi^{2}$ tests were performed between all geographically adjacent samples (Table 4). Significant allele frequency differences over all loci were observed between Christmas Island and Papua New Guinea, between Christmas Island and Japan, between Vanuatu and Niue, and between Niue and the Cook Islands. Additionally, there were significant differences in at least one locus in comparisons between Japan and Papua New Guinea and between Vanuatu and the Cook Islands. The relatively small sample sizes from the 'peripheral' Pacific locations (Japan, Niue and the Cook Islands) in these last two comparisons rendered these statistical tests weak. None of the pairwise comparisons between the 'central' western Pacific populations of Papua New Guinea, Solomon Islands and Vanuatu proved significant (Table 4). These three samples were thus pooled to provide more powerful comparisons with adjacent samples. Additional comparisons with the peripheral Pacific populations showed that each was significantly different from the central group. The difference between the central three population samples and Japan was largely from the difference in allele frequencies in $O D H$ (Table 4). Niue was significantly different at three loci while the Cook Islands were primarily different at one locus, $P G M-2$, where a new allele $\left({ }^{*} 160\right)$ was found.

The major difference in allele frequencies between the Pacific populations and the Christmas Island (Indian Ocean) population occurred in $P E P$ $(P<0.001$; Fig. 2$)$. One allele $\left(P E P^{*} 85\right)$ was found only in the Christmas Island sample, where it occurred at a high frequency $(0.457)$, while another allele $\left(P E P^{*} 110\right)$ was found only among the Pacific samples. Of the 28 alleles observed in total, 13 were restricted to the 
Table 3 Allele frequencies and heterozygosities in ten populations of Birgus latro

Population

\begin{tabular}{|c|c|c|c|c|c|c|c|c|c|c|}
\hline \multirow{2}{*}{$\begin{array}{l}\text { Locus } \\
\text { and } \\
\text { allele }\end{array}$} & \multirow[b]{2}{*}{ Christmas I. } & \multirow[b]{2}{*}{ Japan } & \multirow[b]{2}{*}{ PNG } & \multirow[b]{2}{*}{ Solomon Is. } & \multicolumn{4}{|c|}{ Vanuatu } & \multirow[b]{2}{*}{ Niue } & \multirow[b]{2}{*}{ Cook Is. } \\
\hline & & & & & Santo & Loh & Tegua & Hiu & & \\
\hline \multicolumn{11}{|l|}{ GPI } \\
\hline 100 & 0.994 & 0.976 & 1.000 & 0.966 & 0.951 & 1.000 & 1.000 & 0.976 & 0.966 & 0.940 \\
\hline 125 & 0.000 & 0.000 & 0.000 & 0.027 & 0.038 & 0.000 & 0.000 & 0.024 & 0.034 & 0.060 \\
\hline 108 & 0.000 & 0.024 & 0.000 & 0.000 & 0.000 & 0.000 & 0.000 & 0.000 & 0.000 & 0.000 \\
\hline 70 & 0.006 & 0.000 & 0.000 & 0.007 & 0.011 & 0.000 & 0.000 & 0.000 & 0.000 & 0.000 \\
\hline \multicolumn{11}{|l|}{$M D H-1$} \\
\hline 100 & 1.000 & 1.000 & 0.972 & 1.000 & 1.000 & 0.986 & 1.000 & 0.976 & 0.966 & 1.000 \\
\hline 125 & 0.000 & 0.000 & 0.000 & 0.000 & 0.000 & 0.014 & 0.000 & 0.000 & 0.011 & 0.000 \\
\hline 75 & 0.000 & 0.000 & 0.028 & 0.000 & 0.000 & 0.000 & 0.000 & 0.024 & 0.023 & 0.000 \\
\hline \multicolumn{11}{|l|}{$M D H-2$} \\
\hline 100 & 0.716 & 0.833 & 0.861 & 0.831 & 0.806 & 0.843 & 0.885 & 0.881 & 0.841 & 0.870 \\
\hline 185 & 0.185 & 0.071 & 0.083 & 0.054 & 0.086 & 0.086 & 0.038 & 0.048 & 0.034 & 0.037 \\
\hline 20 & 0.099 & 0.095 & 0.056 & 0.101 & 0.108 & 0.057 & 0.077 & 0.071 & 0.114 & 0.093 \\
\hline-30 & 0.000 & 0.000 & 0.000 & 0.014 & 0.000 & 0.014 & 0.000 & 0.000 & 0.011 & 0.000 \\
\hline \multicolumn{11}{|l|}{$O D H$} \\
\hline 100 & 0.980 & 0.800 & 0.972 & 0.963 & 0.957 & 0.971 & 0.923 & 0.929 & 0.977 & 0.942 \\
\hline 120 & 0.000 & 0.050 & 0.000 & 0.015 & 0.005 & 0.000 & 0.026 & 0.000 & 0.000 & 0.000 \\
\hline 110 & 0.000 & 0.125 & 0.000 & 0.000 & 0.011 & 0.000 & 0.013 & 0.024 & 0.000 & 0.058 \\
\hline 85 & 0.000 & 0.025 & 0.028 & 0.022 & 0.027 & 0.029 & 0.026 & 0.048 & 0.023 & 0.000 \\
\hline 75 & 0.020 & 0.000 & 0.000 & 0.000 & 0.000 & 0.000 & 0.013 & 0.000 & 0.000 & 0.000 \\
\hline \multicolumn{11}{|l|}{ PEP } \\
\hline 100 & 0.543 & 0.929 & 0.806 & 0.878 & 0.908 & 0.871 & 0.833 & 0.881 & 0.784 & 0.963 \\
\hline 110 & 0.000 & 0.071 & 0.194 & 0.122 & 0.092 & 0.129 & 0.167 & 0.119 & 0.216 & 0.037 \\
\hline 85 & 0.457 & 0.000 & 0.000 & 0.000 & 0.000 & 0.000 & 0.000 & 0.000 & 0.000 & 0.000 \\
\hline \multicolumn{11}{|l|}{$P G M-1$} \\
\hline 100 & 0.988 & 0.857 & 0.861 & 0.788 & 0.791 & 0.829 & 0.806 & 0.833 & 0.682 & 0.720 \\
\hline 125 & 0.000 & 0.000 & 0.000 & 0.014 & 0.005 & 0.000 & 0.000 & 0.000 & 0.000 & 0.000 \\
\hline 110 & 0.012 & 0.095 & 0.083 & 0.192 & 0.192 & 0.157 & 0.181 & 0.143 & 0.318 & 0.280 \\
\hline 90 & 0.000 & 0.048 & 0.056 & 0.007 & 0.011 & 0.014 & 0.014 & 0.024 & 0.000 & 0.000 \\
\hline \multicolumn{11}{|l|}{$P G M-2$} \\
\hline 100 & 0.963 & 0.952 & 0.944 & 0.973 & 0.962 & 0.984 & 0.949 & 0.952 & 0.977 & 0.944 \\
\hline 160 & 0.000 & 0.000 & 0.000 & 0.000 & 0.000 & 0.000 & 0.000 & 0.000 & 0.000 & 0.037 \\
\hline 135 & 0.000 & 0.048 & 0.000 & 0.000 & 0.022 & 0.000 & 0.013 & 0.024 & 0.023 & 0.019 \\
\hline 120 & 0.037 & 0.000 & 0.028 & 0.020 & 0.011 & 0.000 & 0.013 & 0.000 & 0.000 & 0.000 \\
\hline 80 & 0.000 & 0.000 & 0.028 & 0.007 & 0.005 & 0.016 & 0.026 & 0.024 & 0.000 & 0.000 \\
\hline$H_{\mathrm{obs}}$ & 0.145 & 0.180 & 0.151 & 0.160 & 0.155 & 0.115 & 0.138 & 0.163 & 0.192 & 0.131 \\
\hline$H_{\exp }$ & 0.156 & 0.169 & 0.151 & 0.150 & 0.156 & 0.131 & 0.152 & 0.151 & 0.184 & 0.151 \\
\hline
\end{tabular}

Sample sizes and location abbreviations are listed in Table 1.

Pacific Ocean, two were restricted to the Indian Ocean, two were restricted to either the Japan or Cook Islands populations, and one was virtually restricted to Japan and the Cook Islands. No alleles were found exclusively in any of the other populations.

Across all seven major populations, both $F_{\mathrm{ST}}$ and $\theta$ equal 0.078 (Table 5). This value is significantly greater than zero $(P<0.001)$, using both a $\chi^{2}$-test and a bootstrap method of calculating confidence intervals. If the genetically similar populations of Papua New Guinea, the Solomon Islands and Vanuatu are pooled (as in the contingency tests $), F_{\mathrm{ST}}$ rises to $0.084(P<0.001)$ and $\theta$ rises to $0.102(P<0.001)$. Although statistically significant, these values indicate only moderate levels of differentiation among populations (Wright, 1978). Among the six Pacific populations alone, $F_{\mathrm{ST}}$ is 0.026 $(P<0.01)$ and $\theta$ is $0.009(P<0.05)$. Once again, if the three central populations are pooled, these values rise 
Table 4 Contingency $\chi^{2}$-tests of allele frequency heterogeneity among locations for Birgus latro

\begin{tabular}{|c|c|c|c|c|c|c|c|c|}
\hline \multirow[b]{2}{*}{ Comparison } & \multicolumn{7}{|c|}{ Loci } & \multirow[b]{2}{*}{ Overall } \\
\hline & $G P I$ & $M D H-1$ & $M D H-2$ & $O D H$ & $P E P$ & $P G M-1$ & $P G M-2$ & \\
\hline \multicolumn{9}{|c|}{ Hierarchical comparisons of populations } \\
\hline All & - & * & ** & $* * *$ & $* * *$ & $* * *$ & * & $* * *$ \\
\hline Pacific & - & * & - & $* * *$ & * & ** & - & $* * *$ \\
\hline Vanuatu & - & - & - & - & - & - & - & - \\
\hline \multicolumn{9}{|l|}{ Adjacent pairwise comparisons } \\
\hline Christmas I. vs. Japan & $*$ & - & - & $* * *$ & $* * *$ & $* * *$ & ** & $* * *$ \\
\hline Christmas I.vs. PNG & - & * & - & - & $* * *$ & $* * *$ & - & $* * *$ \\
\hline Japan vs. PNG & - & - & - & $*$ & - & - & - & - \\
\hline PNG vs. Solomons & - & - & - & - & - & - & - & - \\
\hline Solomons vs. Vanuatu & - & - & - & - & - & - & - & - \\
\hline Vanuatu vs. Niue & - & $*$ & - & - & $*$ & $*$ & - & ** \\
\hline Niue vs. Cook Islands & - & - & - & $*$ & $* *$ & - & - & $*$ \\
\hline \multicolumn{9}{|l|}{ Pooled comparisons } \\
\hline Japan vs. PNG/Sol/Van & - & - & - & $* * *$ & - & - & - & *** \\
\hline Niue vs. PNG/Sol/Van & - & ** & - & - & $*$ & ** & - & ** \\
\hline Cook Islands vs. PNG/Sol/Van & - & - & - & - & - & - & ** & $* *$ \\
\hline
\end{tabular}

$G$-tests (Sokal \& Rohlf, 1981) gave identical results.

,$- \mathrm{NS} ;{ }^{*} P \leqslant 0.05 ;{ }^{* *} P \leqslant 0.01 ;{ }^{* * *} P \leqslant 0.001$.

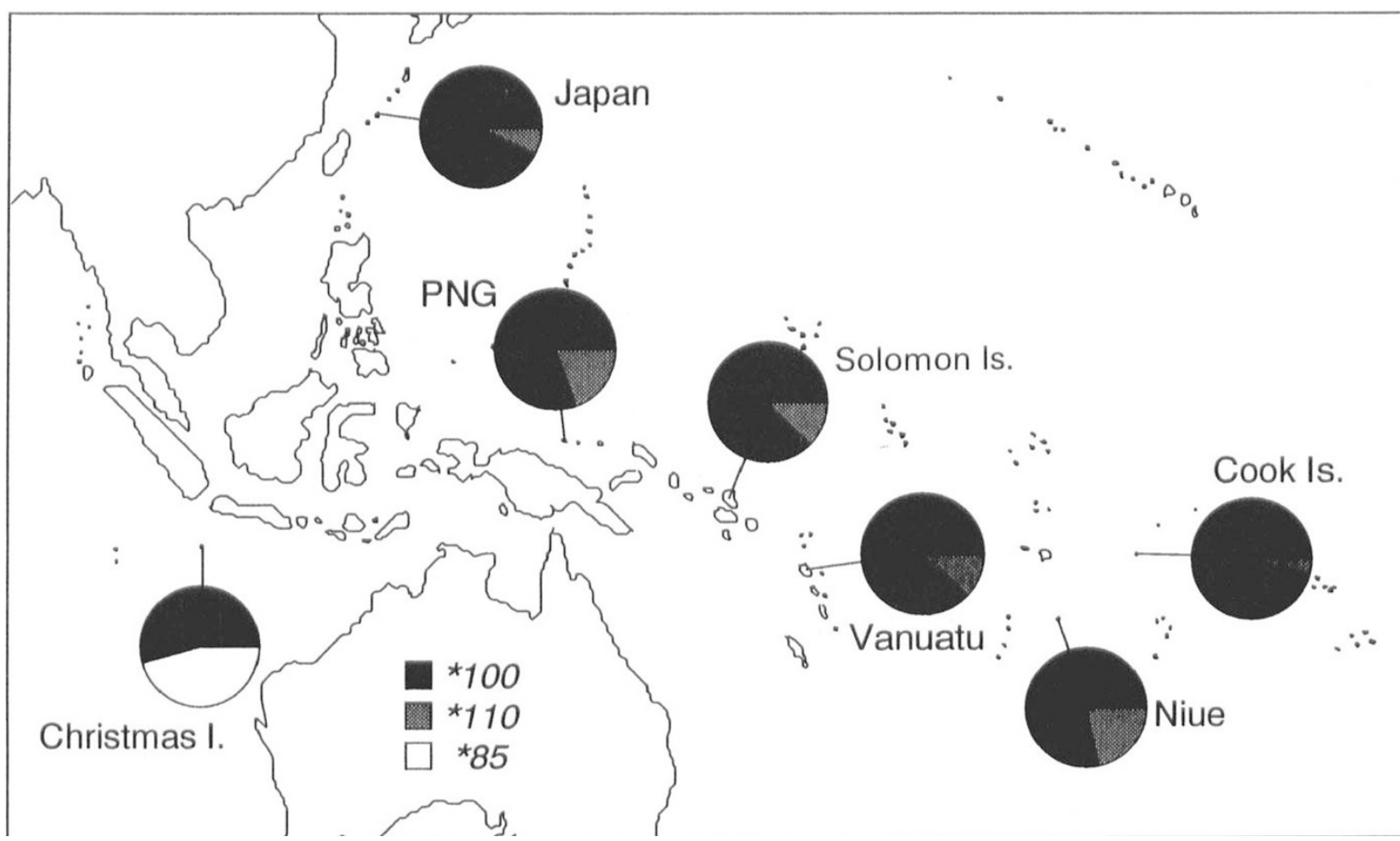

Fig. 2 Birgus latro PEP allele frequencies in seven Indo-Pacific populations. 
Table $5 \mathrm{~F}$-statistics: derived estimates of gene flow $(\mathrm{Nm})$ among Birgus latro populations

\begin{tabular}{|c|c|c|c|c|}
\hline Comparison & $F_{\mathrm{ST}}{ }^{\dagger}$ & $N m\left(F_{\mathrm{ST}}\right)$ & $\theta(95 \%$ C.I. $) \neq$ & $N m(\theta)$ \\
\hline All populations & $0.078^{* * *}$ & 2.89 & $\begin{array}{c}0.078^{* * *} \\
(0.010-0.151)\end{array}$ & 2.89 \\
\hline Pacific populations & $0.026^{* *}$ & 8.51 & $\begin{array}{c}0.009^{*} \\
(0.002-0.018)\end{array}$ & 13.90 \\
\hline Vanuatu populations & 0.006 & 40.60 & $\begin{array}{c}-0.003 \\
(-0.009-0.003)\end{array}$ & - \\
\hline Christmas I. vs. PNG & $0.082^{* * *}$ & 2.74 & $\begin{array}{c}0.134^{* * *} \\
(0.013-0.224)\end{array}$ & 1.57 \\
\hline
\end{tabular}

$\nmid$ Tested for difference from zero using methods of Workman \& Niswander (1970). $\ddagger$ Confidence interval derived from 1000 replications bootstrapped over loci (Weir, 1990).

${ }^{*} P \leqslant 0.05 ;{ }^{* *} P \leqslant 0.01 ;{ }^{* * *} P \leqslant 0.001$.

Table 6 Hierarchical gene diversity analysis among Birgus latro populations

\begin{tabular}{lcc}
\hline Variance component & Total variance & $\begin{array}{c}\text { Variance among } \\
\text { populations }\end{array}$ \\
\hline Within islands & 0.953 & - \\
Among islands within group (Vanuatu) & 0.001 & 0.021 \\
Among groups within Pacific Ocean & 0.017 & 0.362 \\
Between Indian and Pacific Oceans & 0.029 & 0.617 \\
\hline
\end{tabular}

to $0.028(P<0.001)$ and $0.017(P<0.01)$, respectively. These measures of population differentiation in the Pacific are still significantly greater than zero, but substantially lower than those derived from the analysis of both Indian and Pacific Oceans. To quantify more accurately these changes in genetic differentiation at the various spatial scales under consideration, a three-level hierarchical $F$-statistics analysis was performed, and genetic variance was partitioned into its components (Table 6). This analysis shows that 62 per cent of the total genetic variance among populations is the result of differences between the Indian and Pacific Oceans, while 36 per cent is from differences among Pacific island groups. Only 2 per cent was from differences among islands within a group, although this could be tested only among the islands of Vanuatu. A large proportion of the total genetic variance was distributed within populations, as is typical for many marine species (Gyllensten, 1985).

The multidimensional scaling (MDS) pattern of relationships among B. latro populations (Fig. 3) shows that the islands of Vanuatu, Papua New Guinea and the Solomon Islands are very similar, forming a relatively tight central cluster. Each of the more peripheral Pacific populations is relatively distinct from this central group and from each other. Christmas Island in the Indian Ocean is highly divergent from all the Pacific populations. The UPGMA clustering dendrogram was strongly concordant with these results.

To examine the effect of geographical distance on genetic relationships among island populations of $B$. latro, pairwise geographical distances were calculated and plotted against pairwise genetic distances (Fig. 4). All the points involving comparison with Christmas Island stand out clearly from the rest, indicating that the increased genetic distance between this population and the others is certainly not because of the increased distance alone. Among the points plotted from the Pacific populations, there appears to be a distinct linear trend of gradually increasing genetic distance with increasing geographical distance. A Mantel test of this relationship gave a normalized Mantel statistic, $Z$, of 0.77 , which was highly significant $(P=0.001)$. A linear regression was fitted to the points and is shown in Fig. 4. Using the technique of Richardson et al. (1986), the average genetic distance between replicate samples 


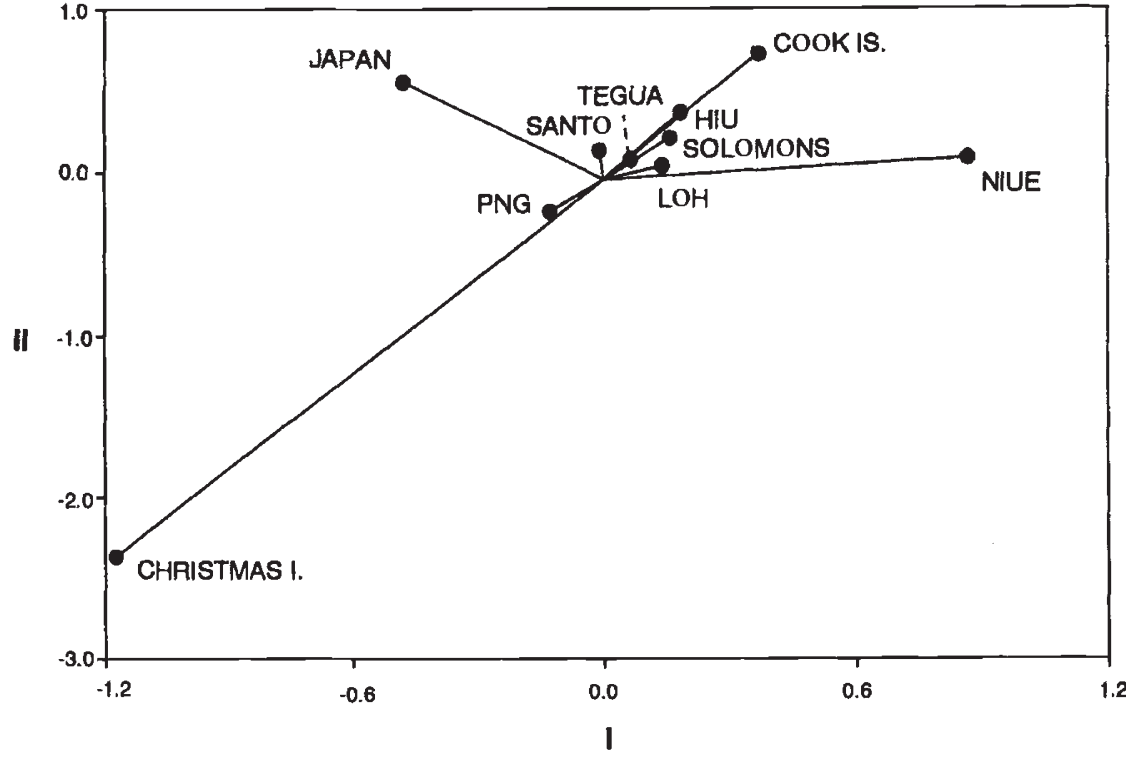

Fig. 3 Multidimensional scaling (MDS) pattern of genetic relationships among Birgus latro island populations examined. Rogers's modified genetic distances (Wright, 1978) were used, and relationships plotted in two dimensions. from one location can be used to estimate a genetic neighbourhood distance from the regression of genetic distance on geographical distance. The average genetic distance between replicate samples in each of the Solomon Islands, Espiritu Santo and Niue was 0.048. Interpolating from the regression line gives a genetic neighbourhood distance (distinct from Wright's neighbourhood size; Wright, 1978), of approximately $2000 \mathrm{~km}$ for B. latro (Fig. 4). That is, in general, Pacific populations closer than $2000 \mathrm{~km}$ to each other are likely to be genetically uniform.

\section{Discussion}

\section{Genetic variation and gene flow}

Two of the principal questions addressed by this study are whether there is significant geographical variation in allozymes from $B$. latro and, if so, over what geographical scale it occurs. The results provide clear evidence for geographically structured genetic variation in this species. The same pattern of population differentiation was found from all the statistical analyses (contingency $\chi^{2}, F_{\mathrm{ST}}$, genetic distance) and is best summarized by the MDS pattern (Fig. 3). The $B$. latro populations from the islands of Vanuatu, the Solomon Islands and Papua New Guinea are very similar. The more peripheral Pacific populations, Japan, Niue and the Cook Islands, all appear to be somewhat differentiated from the central populations and from each other. Christmas Island in the Indian Ocean is clearly differentiated from all the Pacific populations. It is clear from the plot of genetic vs. geographical distance that this greater differentiation of

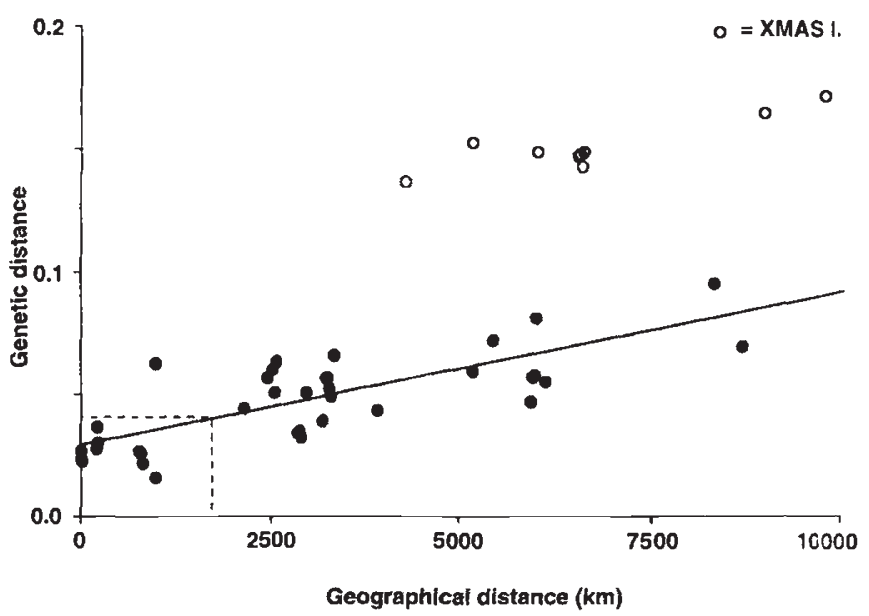

Fig. 4 Relationship between genetic and geographical distance among Birgus latro populations. Points plotted are Rogers's modified genetic distances and over-water geographical distances between all pairs of populations. Open circles indicate values for all pairwise combinations that include Christmas Island (Xmas I.). A regression line is plotted for all points from Pacific pairs (closed circles) $\left(Y=7.26 \times 10^{-6} X+0.035 ; r=0.77, P<0.001\right)$. Also plotted (dashed lines) is the intercept on this regression of the average genetic distance between replicate sample sets $(0.048)$, which gives a genetic neighbourhood distance $(X$ intercept) of approximately $2000 \mathrm{~km}$. See text for further explanation.

the Indian Ocean is not simply because of a greater spatial distance, but that there must exist a much stronger barrier to gene flow between the two oceans than between any islands in the Pacific. This point is addressed in greater detail below. 
The estimated values of gene flow $(\mathrm{Nm}$, the number of migrants between populations per generation) vary somewhat depending on their derivation $\left(F_{\mathrm{ST}}\right.$ or $\theta$; Table 5). However, the pattern of gene flow in both sets of data is consistent with the pattern of population differentiation described above. Slatkin \& Barton's (1989) simulations did show that $\theta$ over-estimated $\mathrm{Nm}$ when gene flow was great and when sample size was small, therefore the lower estimates of $\mathrm{Nm}$ based on $F_{\mathrm{ST}}$ are probably less biased for the comparisons among Pacific populations. Overall, gene flow $(\mathrm{Nm})$ appears to be of the order of one to three individuals per generation between the Pacific and Indian Oceans, approximately 10-20 individuals per generation among Pacific populations, and very high ( $>40$ individuals per generation) among islands within a group. However, these are abstract estimates and their standard errors are poorly known.

\section{Geographical scale and genetic population structure}

The three models of population structure that have been usually analysed theoretically in the literature are: (i) panmixia, characterized by long-distance gene flow where the entire population behaves as a single homogeneous unit, (ii) the island model, where distinct, isolated populations exchange genes at an equal rate between all 'islands' (Wright, 1978), and (iii) the isolation by distance model, where all populations are connected by gene flow, but genetically effective migration is greatest between neighbouring populations (Wright, 1943). In the case of $B$. latro, the most applicable model varies with the geographical scale being considered. $B$. latro inhabiting the adjacent islands of Vanuatu, plus the neighbouring islands of the Solomons and Papua New Guinea, appear to resemble closely a panmictic population. At the other extreme, $B$. latro populations from each of the Indian Ocean and the Pacific Ocean appear to be discrete 'islands'. Among the Pacific island groups, the relationship between geographical and genetic distance (Fig. 4) provides good evidence that the Pacific populations fit an isolation by distance model. It is unfortunate that it was not possible to obtain samples from elsewhere in the Indian Ocean to test if this model also applies there.

The population structure in the Pacific appears to tie in well with the distribution of islands throughout the Pacific range of the species. Namely, where there exists a continuous chain of islands, each separated by only a short distance (as in the case of Papua New Guinea, the Solomon Islands and Vanuatu, where the greatest distance separating two islands is only about $350 \mathrm{~km}$ ), gene flow is enhanced, probably by a stepping-stone effect. This has resulted in a genetic neighbourhood distance (beyond which significant genetic differentiation occurs) of approximately $3000 \mathrm{~km}$ between Papua New Guinea and Vanuatu. This is somewhat greater than the average neighbourhood distance of around $2000 \mathrm{~km}$ calculated over the entire Pacific distribution. The position of Japan is also interesting in this regard, as the genetic distance between this population and that of Papua New Guinea is less than that expected from geographical distance alone. Once again, a chain of islands extending through the Philippines links these two locations, with intervening ocean distances of no greater than $150 \mathrm{~km}$. A strong northward flowing oceanic current (the Kuroshio) also links the two locations. Where islands are separated by great expanses of ocean, without intervening islands (for example, at least $650 \mathrm{~km}$ of ocean surrounding Niue and approximately $700 \mathrm{~km}$ isolating Suwarrow in the Cook Islands), gene flow is more restricted and genetic neighbourhoods smaller. It is interesting that $B$. latro never appeared to reach the Hawaiian Islands, which are separated by at least $2000 \mathrm{~km}$ (and the westward flowing North Pacific Equatorial Current) from the nearest islands inhabited by this species. Birgus latro had no such difficulty colonizing the Tuamotus against the South Pacific Equatorial Current, presumably because of the existence of an irregular chain of islands extending eastwards from the Cook Islands (with maximum interisland distance of about $500 \mathrm{~km}$ ). It therefore appears that the presence of stepping-stone islands, rather than geographical distance or currents alone, is the most important factor influencing Pacific Ocean gene flow in this species.

The pronounced genetic differentiation between Pacific and Indian Ocean populations of $B$. latro is more surprising. The geographical distance between Christmas Island and Papua New Guinea is similar to that between Papua New Guinea and Japan, but the genetic distances are very different (Fig. 3). Also, the interisland distance along the island chain between Christmas Island and Papua New Guinea is again small, being no greater than $350 \mathrm{~km}$. Birgus latro is known to occur still on some islands in the Indonesian archipelago (in particular, islands around Sulawesi), therefore it is likely that the species did once inhabit many of these islands and has disappeared only since the arrival of humans. The reason for the distinct genetic difference between the Christmas Island and Papua New Guinea populations thus requires some further explanation. It is possible that differential selection may be acting on the Pacific and Indian Ocean populations. However, the concordance in the pattern of geographical variation among most of the seven independent loci suggests that this is unlikely. Also, reduced mixing of Pacific and Indian Ocean gene pools as a result of the absence of fast mid-ocean currents is 
not likely to provide a complete answer, as fast tidal and seasonal currents flowing between the two oceans are prevalent throughout the Indonesian region (Murray \& Arief, 1988). A more likely cause of gene pool segregation may lie in the considerable periods of lowered sea levels during the late Pleistocene (Chappell \& Shackleton, 1986), when a substantial land bridge existed between much of South-east Asia and Australia. At these times, water flow between the Indian and Pacific Oceans was probably much more restricted than in recent times (McManus, 1985), resulting in a prolonged period of reduced gene flow via currents between oceans. Furthermore, as B. latro can apparently survive only on small islands free from large predators (Brown \& Fielder, 1991), it is probable that few populations existed on the large South-east Asian land bridge during the period of lowered sea levels. This would have further isolated the Indian and Pacific Ocean B. latro populations by restricting the extent of stepping-stone gene flow between the oceans. It is therefore possible that the genetic separation between Indian and Pacific Ocean populations of $B$. latro dates from that late Pleistocene period.

There is some morphological evidence from other species to support a prolonged, historical isolation of Indian and Pacific Ocean gene pools. A number of pairs of species or subspecies of mollusc (strombids), fish (siganids) and echinoderms are divided into Indian and Pacific Ocean populations in a similar manner (McManus, 1985). However, no genetic studies have yet been undertaken to examine this situation.

It appears that there are no major unrecognized barriers to restrict $B$. latro planktonic gene flow within the Pacific Ocean, at least among the locations examined in this study. This pattern is also evident in the few other Pacific species with planktonic larval dispersal which have been examined genetically. For example, the crown-of-thorns starfish (Acanthaster planci) has a population structure which also follows an isolation by distance pattern in the Pacific (Nishida \& Lucas, 1988; Benzie, 1992). Acanthaster planci, along with the giant clam Tridacna derasa, have slightly shorter larval periods of approximately 2 weeks, and both species exhibit slightly higher levels of genetic differentiation among Pacific populations than does $B$. latro (Benzie, 1992; Macaranas et al., 1992). However, it is yet to be seen if these species also exhibit a change in the pattern of population subdivision as the geographical scale under consideration goes from the Pacific to the Indo-Pacific. Only when representative Pacific and Indian Ocean populations of these and other species are examined will it become clear if pronounced genetic differentiation between the Pacific and Indian Oceans is a characteristic feature of IndoPacific species dependent on marine larval dispersal.

\section{Acknowledgements}

Assistance with sample collection was provided by (among others): C. Schiller and R. Fletcher (co-investigators); A. Carlot and W. Bakeo (Vanuatu); D. Phillips and P. Goh (Christmas Island); P. Nichols and S. Diake (Solomon Islands); S. Talagi, B. Punu and T. Mautama (Niue); J. Dashwood, K. Passfield and T. Rongo (Cook Islands); P. Bacolod (Philippines); A. Wafy (PNG); and T. Hayashibara, N. Oshiro and A. Ebisawa (Japan). Financial assistance was provided by the Australian Centre for International Agricultural Research, an Australian Postgraduate Research Award (to S.L.), the Linnean Society of New South Wales, the Australian Marine Sciences Association and the University of Queensland.

\section{References}

BENZIE, J. A. H. 1992. Review of the genetics, dispersal and recruitment of Crown-of-thorns starfish (Acanthaster plancii). Aust. J. Mar. Freshw. Res., 43, 597-610.

BRown, I. W. AND FIELDER, D. R. 1991. The Coconut Crab: Aspects of Birgus latro Biology and Ecology in Vanuatu. Australian Centre for International Agricultural Research, Canberra.

BURTON, R. 1983. Protein polymorphism and genetic differentiation of marine invertebrate populations. Mar. Biol. Lett., 4, 193-206.

CHAKRABORTY, R. AND DANKER-HOPFE, H. 1991. Analysis of population structure: a comparative study of different estimators of Wright's fixation indices. In: Rao, C. R. and Chakraborty, R. (eds) Handbook of Statistics, vol. 8, pp. 203-254. Elsevier, Amsterdam.

CHAPPELL, J. AND SHACKLETON, N. J. 1986. Oxygen isotopes and sea level. Nature, 324, 137-140.

GYLLENSTEN, U. 1985. The genetic structure of fish: differences in the intraspecific distribution of biochemical variation between marine, anadromous and freshwater species. $J$. Fish Biol., 26, 691-699.

HEDGECOCK, D. 1986. Is gene flow from pelagic larval dispersal important in the adaptation and evolution of marine invertebrates? Bull. Mar. Sci., 39, 550-564.

KARTAVTSEV, Y. P., BERENBOIM, B. I. AND ZGUROVSKY, K. I. 1991. Population genetic differentiation of the pink shrimp, Pandalus borealis Kroyer, 1838, from the Barents and Bering seas. J. Shellfish Res., 10, 333-339.

KOEHN, R. K., NEWELL, R. I. E. AND IMMERMANN, F. 1980. Maintenance of an aminopeptidase allele frequency cline by natural selection. Proc. Natl. Acad. Sci. U.S.A., 77, 5385-5389.

LAVERY, S. AND FIELDER, D. R. 1993. Low allozyme variation in the coconut crab Birgus latro. Comp. Biochem. Physiol., 104B, 353-359.

LESSA, E. P. 1990. Multidimensional analysis of geographic genetic structure. Syst. Zool., 39, 242-252.

LESSIOS, H. A. 1992. Testing electrophoretic data for agreement with Hardy-Weinberg expectations. Mar. Biol., 112, 517-523.

(c) The Genetical Society of Great Britain, Heredity, 74, 531-541. 
LINDENFELSER, M. E. 1984. Morphometric and allozymic congruence: Evolution in the prawn Macrobrachium rosenbergii (Decapoda, Palaemonidae). Syst. Zool., 33, 195-204.

MACARANAS, J. M., ABLAN, C. A., PANTE, M. J. R., BENZIE, J. A. H., AND WILliams, S. T. 1992. Genetic structure of giant clam (Tridacna derasa) populations from reefs in the IndoPacific. Mar. Biol., 113, 231-238.

McCONAUGHA, J. R. 1992. Decapod larvae: dispersal, mortality, and ecology. A working hypothesis? Am. Zool., 32, 512-523.

McMANUS, J. w. 1985. Marine speciation, tectonics and sealevel changes in southeast Asia. Proceedings of the Fifth Coral Reef Congress, Tahiti, 4, 133-138.

MENZIES, R. A. 1991. Allozyme variation and conservation: applications to spiny lobsters and crocodilians. In: Seitz, A. and Loeschcke, V. (eds) Species Conservation: A Population-Biological Approach. pp. 121-139. Birkhauser Verlag, Basel.

MULLEY, J. AND LATTER, B. 1981a. Geographic differentiation of eastern Australian penaeid prawn populations. Aust. J. Mar. Freshw. Res., 32, 889-895.

MULLEY, J. AND LATTER, B. 1981 b. Geographic differentiation of tropical Australian penaeid prawn populations. Aust. J. Mar. Freshw. Res., 32, 897-906.

MURRAY, S. P. AND ARIEF, D. 1988. Throughflow into the Indian Ocean through the Lombok Strait, January 1985-January 1986. Nature, 333, 444-447.

NEI, M. 1977. $F$-statistics and analysis of gene diversity in subdivided populations. Ann. Hum. Genet., 41, 225-233.

NEI, M. AND CHESSER, R. K. 1983. Estimation of fixation indices and gene diversities. Ann. Hum. Genet., 47, 253-259.

NISHIDA, M. AND LUCAS, J. s. 1988. Genetic differences between geographic populations of the Crown-of-thorns starfish throughout the Pacific region. Mar. Biol., 98, 359-368.

PALUMBI, S. R. 1992. Marine speciation on a small planet. Trends Ecol. Evol., 7, 114-118.

REEB, C. A. AND AVISE, J. C. 1990. A genetic discontinuity in a continuously distributed species: mitochondrial DNA in the American oyster, Crassostrea virginica. Genetics, 124, 397-406.

REESE, E. S. AND KINZIE, R. A. 1968. The larval development of the coconut or robber crab Birgus latro L. in the laboratory (Anomura: Paguridae). Crustaceana Suppl., 2, 117-144.

RICHARDSON, B. J., BAVERSTOCK, P. R. AND ADAMS, M. 1986. Allozyme Electrophoresis: A Handbook for Animal Systematics and Population Studies. Academic Press, Sydney.

ROHLF, F. J. 1990. NTSYs-pc: Numerical Taxonomy and Multivariate Analysis System. Exeter Software, New York.

SALIN!, J. 1987. Genetic variation and population subdivision in the greentail prawn Metapenaeus bennettae. Aust. J. Mar. Freshw. Res., 38, 339-349.

SCHILLER, C., FIELDER, D. R., BROWN, I. W. AND OBED, A. 1991. Reproduction, early life-history and recruitment. In: Brown, I. W. and Fielder, D. R. (eds) The Coconut Crab:
Aspects of Birgus latro Biology and Ecology in Vanuatu, pp. 13-34. Australian Centre for International Agricultural Research, Canberra.

SHAKLEE, J. B., ALLENDORF, F. W., MORIZOT, D. C. AND WHITT, G. S. 1990. Genetic nomenclature for protein coding loci in fish. Trans. Am. Fish. Soc., 119, 2-15.

SHAKLEE, J. B. AND KEENAN, C. P. 1986. A practical laboratory guide to the techniques and methodology of electrophoresis and its application to fish fillet identification. Australian CSIRO Marine Laboratory Report, No. 177, 1-59.

SLATKIn, M. 1985. Gene flow in natural populations. Ann. Rev. Ecol. Syst., 16, 393-430.

SLATKIN, M. AND BARTON, N. H. 1989. A comparison of three indirect methods for estimating average levels of gene flow. Evolution, 43, 1349-1368.

SMOUSE, P. E., LONG, J. C. AND SOKAL, R. R. 1986. Multiple regression and correlation extensions of the Mantel test of matrix correspondence. Syst. Zool., 35, 627-632.

SNEATH, P. H. AND SOKAL, R. R. 1973. Numerical Taxonomy. W. H. Freeman, San Francisco.

SOKAL, R. R. AND ROHLF, F. J. 1981. Biometry. The Principles and Practice of Statistics in Biological Research, 2nd edn. W. H. Freeman, New York.

STEVENS, P. M. 1991. A genetic analysis of the pea crabs (Decapoda: Pinnotheridae) of New Zealand. II. Patterns and intensity of spatial population structure in Pinnotheres atrinocola. Mar. Biol., 108, 403-410.

SWOFFORD, D. L. AND SELANDER, R. B. 1981. BIOSYS-1: a Fortran program for the comprehensive analysis of electrophoretic data in population genetics and systematics. J. Hered., 72, 281-283.

TRACEY, M. L., NELSON, K., HEDGECOCK, D., SHLESER, R. A. AND PRESSICK, M. L. 1975. Biochemical genetics of lobsters: genetic variation and the structure of American lobster (Homarus americanus) populations. J. Fish. Res. Board Can., 32, 2091-2101.

WAPLES, R. 1987. A multispecies approach to the analysis of gene flow in marine shore fishes. Evolution, 41, 385-400.

WAPLES, R. S. 1989. Temporal variation in allele frequencies: testing the right hypothesis. Evolution, 43, 1236-1251.

WEIR, B. S. 1990. Intraspecific differentiation. In: Hillis, D. M. and Moritz, C. (eds) Molecular Systematics, pp. 373-410. Sinauer, Sunderland, MA.

WEIR, B. S. AND COCKERHAM, C. C. 1984 . Estimating $F$-statistics for the analysis of population structure. Evolution, 38, 1358-1370.

WELLS, S. M., PYLE, R. M. AND COLLINS, N. M. 1983. Coconut or robber crab. In: IUCN Invertebrate Red Data Book, pp. 309-316. IUCN, Gland, Switzerland.

WORKMAN, P. L. AND NISWANDER, J. D. 1970 . Population studies on southwestern Indian tribes. II. Local genetic differentiation in the Papago. Am. J. Hum. Genet., 22, 24-49.

Wright, s. 1943. Isolation by distance. Genetics, 28, 114-138.

WRIGHT, s. 1978. Evolution and the Genetics of Populations, vol. 4, Variability Within and Among Natural Populations. University of Chicago Press, Chicago. 